\title{
Seasonal variation in gas exchange by plants of Erythroxylum simonis
}

\section{Plowman}

\section{João Everthon da Silva Ribeiro ${ }^{1 *}$, Ana Jéssica Soares Barbosa', Sérgio de Faria Lopes², Walter Esfrain Pereira and Manoel Bandeira de Albuquerque ${ }^{1}$}

Received: June 23, 2017

Accepted: January 2, 2018

\begin{abstract}
Erythroxylum simonis is an understory species found in Northeast Brazil. Due to its shaded habitat, E. simonis is subjected to seasonal oscillations of the environment, to which it must respond ecophysiologically. The objective of this study was to evaluate the effects of seasonality on the ecophysiology of $E$. simonis in a fragment of Seasonal Semideciduous Forest. Leaf area index, visible sky fraction and photosynthetically active radiation were measured for 10 individuals during the dry and rainy seasons. Soil moisture, temperature and monthly precipitation were measured, as well as photosynthetic rate, stomatal conductance, internal $\mathrm{CO}_{2}$ concentration, transpiration, instantaneous water use efficiency, instantaneous carboxylation efficiency and chlorophyll content. Ecophysiological variables were correlated with environmental variables, with a greater association of rainfall and soil moisture with stomatal conductance, transpiration and photosynthetic rate, indicating that water availability has an effect on the ecophysiology of $E$. simonis. With the exception of instantaneous carboxylation efficiency, gas exchange exhibited significant differences among the months studied, with the highest values being for months with greater water availability, thus showing that the ecophysiology of the species responds to seasonal changes throughout the year.
\end{abstract}

Keywords: ecophysiological responses, photosynthetic rate, seasonal changes, Seasonal Semideciduous Forest, understory

\section{Introduction}

Tropical forests are ecosystems of great importance and are known for their tremendous biodiversity, which is one of the factors that contribute to the great diversity of ecological niches therein (Gardner et al. 2010). Tropical forests account for half of the carbon fixed by plants, exerting a significant influence on global carbon balance and reducing the effects of carbon sequestration in the atmosphere (Pan et al. 2011). Among the diverse types of tropical forest are seasonal forests, which are characterized by two seasons: a dry season and a rainy season. In this type of vegetation, leaf abscission is frequently associated with the dry season (Pennington et al. 2006), which may be directly related to the low rainfall rates during this period, resulting in greater water stress for the species (Braz et al. 2000; Silvério \& Lenza 2010; Rebelatto et al. 2013). The effect of season on growth and development of forest species mainly impacts vegetation located in the understory, where young individuals of canopy tree species are located, including small trees that will never reach the canopy during their life cycle (Prado Júnior et al. 2015), in addition to shrubs, palms, arborescent embryos, seedlings and herbs (Oliveira et al. 2001).

\footnotetext{
1 Programa de Pós-Graduação em Agronomia, Centro de Ciências Agrárias, Universidade Federal da Paraíba, 58397-000, Areia, PB, Brazil 2 Programa de Pós-Graduação em Ecologia e Conservação, Departamento de Biologia, Universidade Estadual da Paraíba, 58429-500, Campina Grande, PB, Brazil
}

* Corresponding author: j.everthon@hotmail.com 
Understory species are influenced by different factors, which can be modified according to the seasonality of the environmental conditions, and consequently alter plant ecophysiology (Davis et al. 1999; Silva et al. 2010; LagePinto et al. 2015). Among the abiotic factors that most influence the ecophysiological responses of understory species are water availability (Palhares et al. 2010; Flexas et al. 2012; Marenco et al. 2014), luminosity (Almeida et al. 2004; Vieira 2013; Leal 2016) and temperature (LemosFilho 2000; Marenco \& Lopes 2009; Taiz \& Zeiger 2013).

Water availability is one of the main limiting environmental factors for photosynthesis, because soil water deficiency results in the gradual reduction of photosynthesis by greater resistance to $\mathrm{CO}_{2}$ fixation due to the closure of the stomata (Nepstad et al. 2002; Mendes 2009). In addition to water availability, luminosity may also limit the growth and ecophysiological development of understory plants. In tropical forests, for example, irradiance is quite variable, with less that $10 \mu \mathrm{mol} \mathrm{m}^{-2} \mathrm{~s}^{-1}$ in the understory and more than $1000 \mu \mathrm{mol} \mathrm{m}^{-2} \mathrm{~s}^{-1}$ in moderate clearings (Mendes 2009).

Floristic structure and composition and canopy openings, as well as small openings caused by canopy leaf fall during the dry season, may influence the ecophysiology of understory species (Frazer et al. 1999; Pezzopane et al. 2002; 2005; Balch et al. 2013; Mendes et al. 2013a). In this sense, some ecophysiological variables, such as the leaf area index (LAI), visible sky fraction VSF) and photosynthetically active radiation (PAR), of understory species can be used as indices to infer the degree of light available in the understory (Mendes et al. 2013b). A variety of different techniques have been used to analyze the structure of the canopy and the transmission of light, such as the use of hemispheric photographs (Bianchini et al. 2001; Guariguata \& Kattan 2002; Zhang, et al. 2005; Monte et al. 2007; Silva et al. 2009; Rody et al. 2014; Moraes et al. 2016), as well as LAI meters for attenuation of solar radiation (Welles \& Norman 1991; Kunz et al. 2007), among others.
Erythroxylum simonis (Erythroxylaceae) is typical of the understory and is endemic to the Northeast Region of Brazil, where it occurs in the states of Paraíba, Pernambuco, Sergipe, Ceará and Rio Grande do Norte. It is found in humid Atlantic Forest and in brejos de altitude (Seasonal Semideciduous Forests) (Loiola et al. 2007; Loiola \& Costa-Lima 2015). This species is of high significance in these regions, mainly with regard to the preservation of endemic genetic resources and as a source of food for fauna (Fabricante 2013). However, there is little information on the ecophysiology of understory species that would be useful in designing models that seek to predict carbon sequestration scenarios, as well as explain the dynamics of the community in the understory of seasonal tropical forests.

The objective of this study was to evaluate the effects of seasonality on the ecophysiology of Erythroxylum simonis. The hypothesis is that the species' ecophysiology is seasonally dependent, and exhibits lower values for physiological variables during the dry season as an economic strategy under water stress due low rainfall and higher light and temperature (caused by foliar deciduousness), which consequently decreases soil moisture.

\section{Materials and methods}

\section{Study area}

The study was undertaken in Parque Estadual Mata do Pau-Ferro, in the municipality of Areia located in the micro-region of Brejo and mesoregion of Agreste Paraibano, state of Paraíba (PB), Northeast Region of Brazil (6 $6^{\circ} 58^{\prime} 12^{\prime \prime S}$ $35^{\circ} 42^{\prime} 15^{\prime \prime} \mathrm{W}$ ) (Fig. 1). The climate of the region is tropical and classified as Aw according to Peel et al. (2007), which is characterized as hot and humid with autumn-winter rains. The elevation of the region varies between 400 and 600

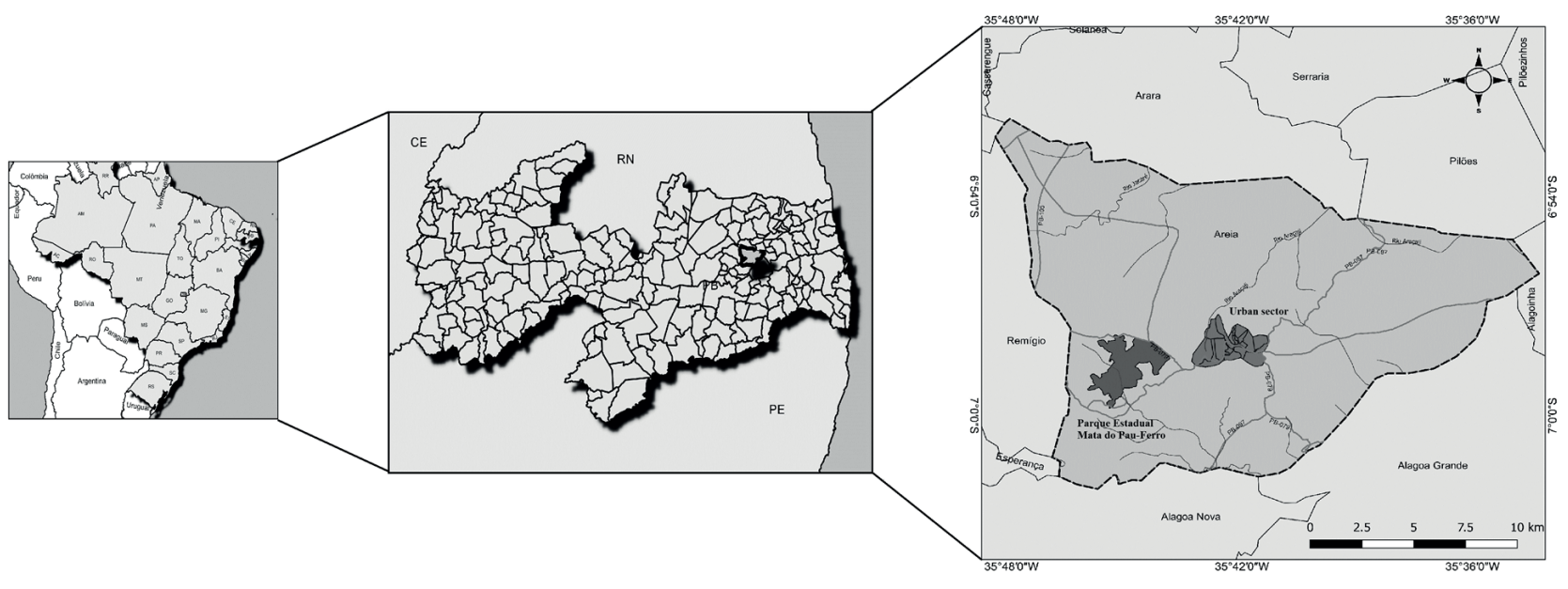

Figure 1. Geographic location of Parque Estadual Mata do Pau-Ferro, municipality of Areia, state of Paraíba, northeast Region of Brazil. 
meters, with the mean annual temperature being 22o C and the annual rainfall $1.400 \mathrm{~mm}$ (Mayo \& Fevereiro 1982; Barbosa et al. 2004; Oliveira et al. 2006; Silva et al. 2006).

The study area is a fragment of the extremely endangered Brejo de Altitude, a plant formation of the Atlantic Forest. The fragment in question encompasses approximately 600 hectares situated five kilometers from the seat of the municipality of Areia, PB. The local vegetation is partially degraded, with signs of disturbance mainly near the urban area, and with little of the original vegetation that covered the municipality remaining. The forest fragment is one of the few forest remnants of Brejos de Altitude in the Northeast Region of Brazil, and is one of the most representative.

\section{Data collection}

The months for data collection in each season were selected according to data from the ombrothermal diagram of the last 30 years for the city of Areia, PB (Fig. 2). Bimonthly readings were made in March, May and July for the rainy season and in September, November and January for the dry season.

For the collection of ecophysiological data, 10 adult individuals with diameters at chest height and mean heights of $18 \mathrm{~cm}$ and $3 \mathrm{~m}$, respectively, were randomly selected. All individuals were tagged and georeferenced. To characterize the soil of the experimental area, a simple surface soil sample
(0-20 cm depth) was collected under the canopy of each individual, which were combined to form a composite sample that was submitted to chemical and physical (granulometric) analyses (Tab. 1).

In order to determine gas exchange, the rate of photosynthesis $(\mathrm{A})\left(\mu \mathrm{mol} \mathrm{m} \mathrm{s}^{-2}\right)$, internal $\mathrm{CO}_{2}$ concentration (Ci) $\left(\mu \mathrm{mol} \mathrm{mol} \mathrm{m}^{-1}\right)$, transpiration (E) $\left(\mathrm{mmol} \mathrm{m}^{-2} \mathrm{~s}^{-1}\right)$ and stomatal conductance (gs) $\left(\mathrm{mol} \mathrm{m}^{-2} \mathrm{~s}^{-1}\right)$ were measured. From these data the instantaneous water use efficiency (IWUE, A/E) and instantaneous carboxylation efficiency (ICE, A/Ci) were calculated (Zhang et al. 2001; Machado et al. 2005; Melo et al. 2009; Brito et al. 2012). Measurements were performed on the middle third of the plants on healthy, and fully expanded leaves using a portable infrared gas analyzer (IRGA) (ACD, model LCPro SD, Hoddesdon, UK). Readings of gas exchange were made between 10:00 am and 11:00 am. Relative chlorophyll content was measured using a Soil Plant Analysis Development chlorophyll meter (SPAD-502, Minolta, Japan), at four points on the middle third of the plants and averaged.

Leaf area index (LAI), visible sky fraction (VSF) and photosynthetically active radiation (PAR) above individual plants of E. simonis, located in the understory were estimated using digital hemispheric images with Digital Plant Canopy Imager - CI-110 (CID). The readings and the recording of images were made in diffuse light conditions (in the early morning or late afternoon or on days with uniformly cloudy

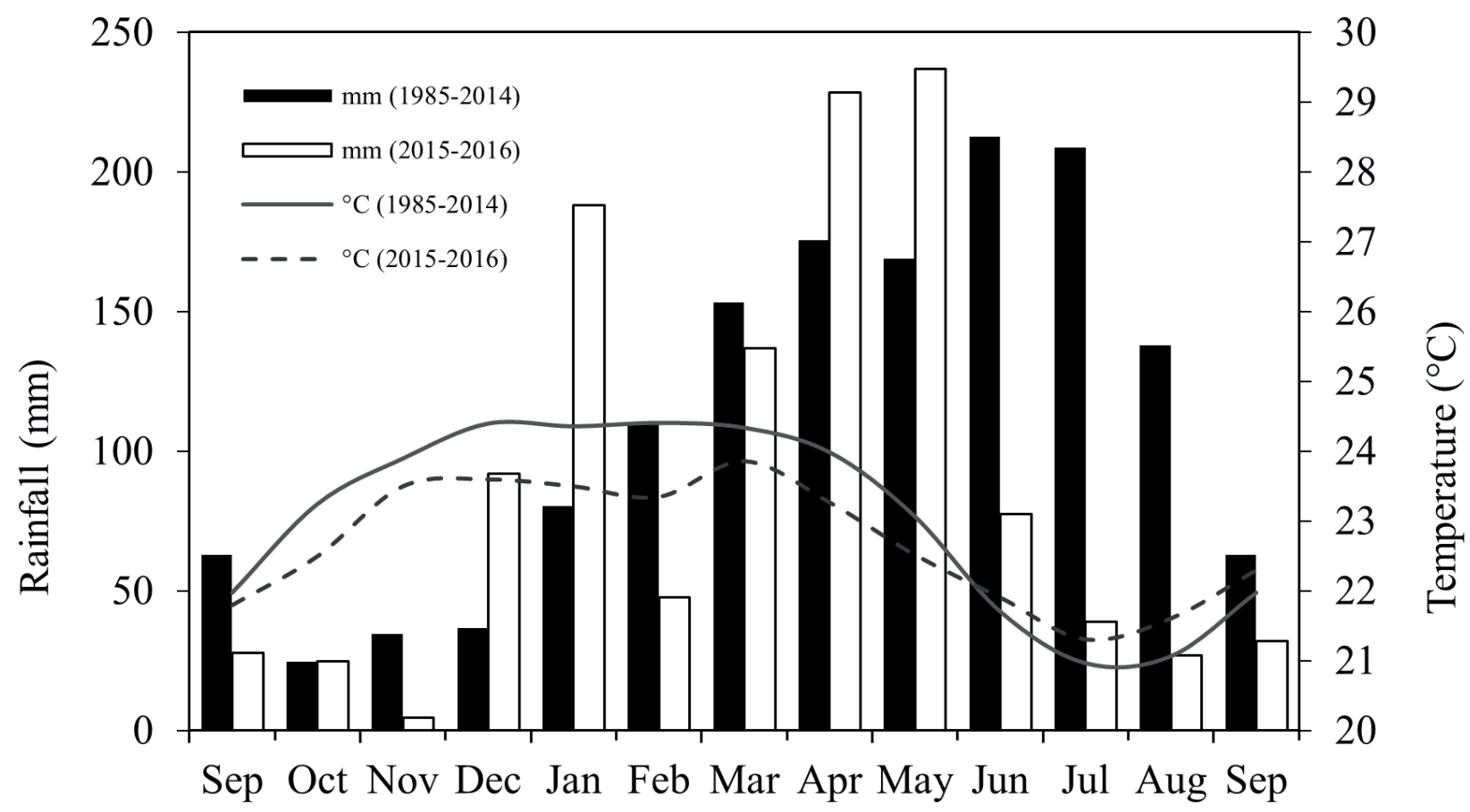

Months

Figure 2. Rainfall and temperature at the Estação Meteorológica do Centro de Ciências Agrárias, Universidade Federal da Paraíba, municipality of Areia, state of Paraiba, Brazil, for the period from September 2015 to September 2016 and the normal average of the last 30 years (1985-2014). 
Table 1. Chemical and granulometric properties of the soil at depth of $0-20 \mathrm{~cm}$ collected in Parque Estadual Mata do Pau-Ferro. Areia. PB.

\begin{tabular}{|c|c|c|c|c|c|c|c|c|c|c|c|c|c|}
\hline \multirow{2}{*}{$\mathrm{pH}$ in $\mathrm{H}_{2} \mathrm{O}$} & $\mathbf{P}$ & K & $\mathrm{Na}$ & $\mathrm{H}+\mathrm{Al}$ & Al & $\mathrm{Ca}$ & $\mathrm{Mg}$ & BS & CEC & \multirow{2}{*}{$\begin{array}{c}0 . \mathrm{M} . \\
\mathrm{g} \mathrm{kg}^{-1}\end{array}$} & \multirow{2}{*}{\multicolumn{3}{|c|}{$\frac{\text { Silt }}{\mathrm{g} \mathrm{kg}^{-1}}$}} \\
\hline & \multicolumn{2}{|c|}{$\mathrm{mg} \mathrm{dm}^{3}$} & \multicolumn{7}{|c|}{$\mathrm{cmolc} \mathrm{dm}^{3}$} & & & & \\
\hline 5 & 4.3 & 111.2 & 0.07 & 4.21 & 0.75 & 0.53 & 0.49 & 1.37 & 5.58 & 19.86 & 653 & 160 & 187 \\
\hline
\end{tabular}

sky) in order to achieve the maximum possible contrast between leaves and sky (Whitford et al. 1995; Galvani \& Lima 2014).

Soil samples were collected to determine moisture content at the time the ecophysiological variables were measured. Soil moisture (SM) was determined according to the gravimetric moisture equation recommended by Klein (2008): SM (\%) = WM-DM. 100/DS, where, SM = soil moisture in \%; WM = wet mass of sample (g); DM = dry mass of sample (g).

\section{Data analysis}

To evaluate associations between environmental variables - Group I (LAI, VSF, PAR, SM, PREC and T) and ecophysiological variables - Group II (A, Ci, E, gs, A/E, $\mathrm{A} / \mathrm{Ci}$ and SPAD) a multivariate analysis was performed employing canonical correlation analysis (CCA) and principle component analysis (PCA). For the analysis of the significance of canonical roots together, Wilks's Lambda multivariate test of significance was used (approximation of the $\mathrm{F}$ distribution). The differences between ecophysiological variables at different times of the year were tested by ANOVA with Tukey's test being used to compare means. All of the analyses were performed using SAS ${ }^{\circ}$ 9.3.5 (Cody 2015).

\section{Results}

\section{Influence of environmental factors on the ecophysiology of E. simonis}

The analyzed ecophysiological variables correlated with the environmental variables according to the CCA, however, only the first and second canonical pair were significant, with $\mathrm{R}^{2}$ values of 0.862 and 0.738 , respectively (Tab. 2), indicating the effects of seasonality on the ecophysiology of $E$. simonis. In the first canonical pair, the most important environmental variables were rainfall and soil moisture (cc of 0.97 and 0.60 , respectively), which were correlated with stomatal conductance, transpiration and photosynthetic rate (cc of $0.85,0.62$ and 0.56 , respectively) (Tab. 3 ).

The principal components analysis (PCA) concentrated $49.1 \%$ of the total variability in the first two components (axes), with $28.55 \%$ in the first and $20.54 \%$ in the second (Fig. 3). Thus, it was possible to observe that stomatal conductance (gs) and transpiration (E) were strongly correlated with precipitation (PREC) and soil moisture content (SM) (Fig. 3). Along the main axis (PC1), the values of the eigenvectors of stomatal conductance and precipitation are positioned to the most extreme right (with positive values), while LAI and PAR are positioned to the left (with negative values), which shows the separation of these two variables from the others analyzed (Fig. 3). Visible sky fraction, temperature, instantaneous water use efficiency and chlorophyll content contributed little to the total since they were located in the median portion of PC1 (Fig. 3).

Table 2. Wilks's Lambda multivariate test (F distribution approximation).

\begin{tabular}{c|c|c|c|c|c|}
\hline $\begin{array}{c}\text { Canonical } \\
\text { function }\end{array}$ & $\mathbf{R}^{2}$ & $\mathbf{F a}$ & $\mathbf{G L}_{1}$ & $\mathrm{GL}_{2}$ & p-value \\
\hline 1 & 0.868 & 3.89 & 42 & 223.9 & $<0.0001$ \\
\hline 2 & 0.738 & 2.20 & 30 & 194.0 & 0.001 \\
\hline 3 & 0.500 & 1.01 & 20 & 163.4 & 0.454 \\
\hline 4 & 0.282 & 0.41 & 12 & 132.57 & 0.954 \\
\hline 5 & 0.119 & 0.13 & 6 & 102.0 & 0.992 \\
\hline
\end{tabular}

Fa: approximate F value; GL1: degrees of freedom regarding treatments; GL2: degrees of freedom regarding error.

Table 3. Canonic correlations and canonical pair between groups I and II characteristics.

\begin{tabular}{|l|c|}
\hline \multicolumn{1}{|c|}{ Variables } & Canonical Pair \\
\hline Group I & \\
\hline Leaf area index (LAI) & -0.34 \\
\hline Visible sky fraction (VSF) & 0.29 \\
\hline Photosynthetically active radiation (PAR) & -0.02 \\
\hline Soil moisture (SM) & 0.60 \\
\hline Precipitation (PREC) & 0.97 \\
\hline Temperature (T) & 0.16 \\
\hline Group II & \\
\hline Rate of photosynthesis (A) & 0.56 \\
\hline Internal CO2 concentration (Ci) & 0.40 \\
\hline Transpiration (E) & 0.62 \\
\hline Stomatal conductance (gs) & 0.85 \\
\hline Instantaneous water use efficiency (IWUE) & -0.14 \\
\hline Instantaneous carboxylation efficiency (ICE) & 0.38 \\
\hline Relative chlorophyll content (SPAD) & 0.19 \\
\hline R2 & 0.86 \\
\hline Significance & $* *$ \\
\hline
\end{tabular}

** Significant at $1 \%$ of probability by chi square test; $\mathrm{R}=$ canonic correlation.

\section{Evaluation of physiological characteristics at different times}

Photosynthetic rate (A) varied from $0.625 \mu \mathrm{mol} \mathrm{m}^{-2} \mathrm{~s}^{-1}$ (November) to $1.357 \mu \mathrm{mol} \mathrm{m}^{-2} \mathrm{~s}^{-1}$ (May) (Fig. 4A). The internal concentration of $\mathrm{CO}_{2} \mathrm{Ci}$ ) decreased in the dry season, mainly in the month of November, ranging from $227.4 \mu \mathrm{mol} \mathrm{m}{ }^{-2} \mathrm{~s}^{-1}$ (November) to $368.0 \mu \mathrm{mol} \mathrm{m}^{-2} \mathrm{~s}^{-1}$ (May) (Fig. 4B). The results for transpiration (E) followed the same trend as stomatal conductance, with significant differences 
between the seasons $(\mathrm{p}<0.001)$, being $73 \%$ higher in the rainy season than in the dry season [varying from $0.221 \mathrm{mmol}$ $\mathrm{m}^{-2} \mathrm{~s}^{-1}$ (November) to $1.357 \mathrm{mmol} \mathrm{m}^{-2} \mathrm{~s}^{-1}$ (May)] (Fig. 4C). Stomatal conductance (gs) also exhibited significant differences among months $(\mathrm{p}<0.001)$, with lowest values in the dry season, varying from $0.02 \mathrm{~mol} \mathrm{~m}^{-2} \mathrm{~s}^{-1}$ (September) to $0.127 \mathrm{~mol} \mathrm{~m}^{-2} \mathrm{~s}^{-1}$ (May) (Fig. 4D). Instantaneous water use efficiency (IWUE) differed significantly between the different study periods $(\mathrm{p}=0.007)$, where a reduction of $27 \%$ was observed between the highest value of $3.830\left[\left(\mu \mathrm{mol} \mathrm{m} \mathrm{m}^{-2} \mathrm{~s}^{-1}\right)\right.$ $\left(\mathrm{mmol} \mathrm{m} \mathrm{m}^{-2} \mathrm{~s}^{-1}\right]$, recorded in the rainy season in May, and the lowest value of $0.900\left[\left(\mu \mathrm{mol} \mathrm{m}^{-2} \mathrm{~s}^{-1}\right)\left(\mathrm{mmol} \mathrm{m}^{-2} \mathrm{~s}^{-1}\right)^{-1}\right]$, recorded in the beginning of the dry season in September (Fig. 4E). Finally, the instantaneous efficiency of carboxylation (ICE), calculated by the ratio $\mathrm{A} / \mathrm{Ci}$, did not show significant differences among the different months of the year $(p=0.165)$. In January the plants had higher instantaneous efficiency of carboxylation; $0.005\left[\left(\mu \mathrm{mol} \mathrm{m}^{-2} \mathrm{~s}^{-1}\right)\right.$ $\left.(\mu \mathrm{mol} \mathrm{mol})^{-1}\right)^{-1}$, resembling the values in May of 0.0049 $\left[\left(\mu \mathrm{mol} \mathrm{m}^{-2} \mathrm{~s}^{-1}\right)\left(\mu \mathrm{mol} \mathrm{mol}^{-1}\right)^{-1}\right]$ (Fig. 4F). Relative chlorophyll content (SPAD) was higher in the rainy season, with values $53 \%$ higher than in the dry season (Fig. 4G), with significant differences among seasons of the year $(p<0.001)$.

\section{Discussion}

Precipitation and soil moisture can be considered the most important variables in relation to stomatal conductance, transpiration and photosynthetic rate of $E$. simonis, according to the results of the CCA (Vessoni 1998; Hair et al. 2005; 2009). There was a positive correlation of stomatal conductance and transpiration with rainfall and soil moisture, demonstrating the influence of water availability on the ecophysiological development of $E$. simonis (Larcher 2006; Marenco \& Lopes 2009). However, it was not possible to explain the lack of response of gaseous

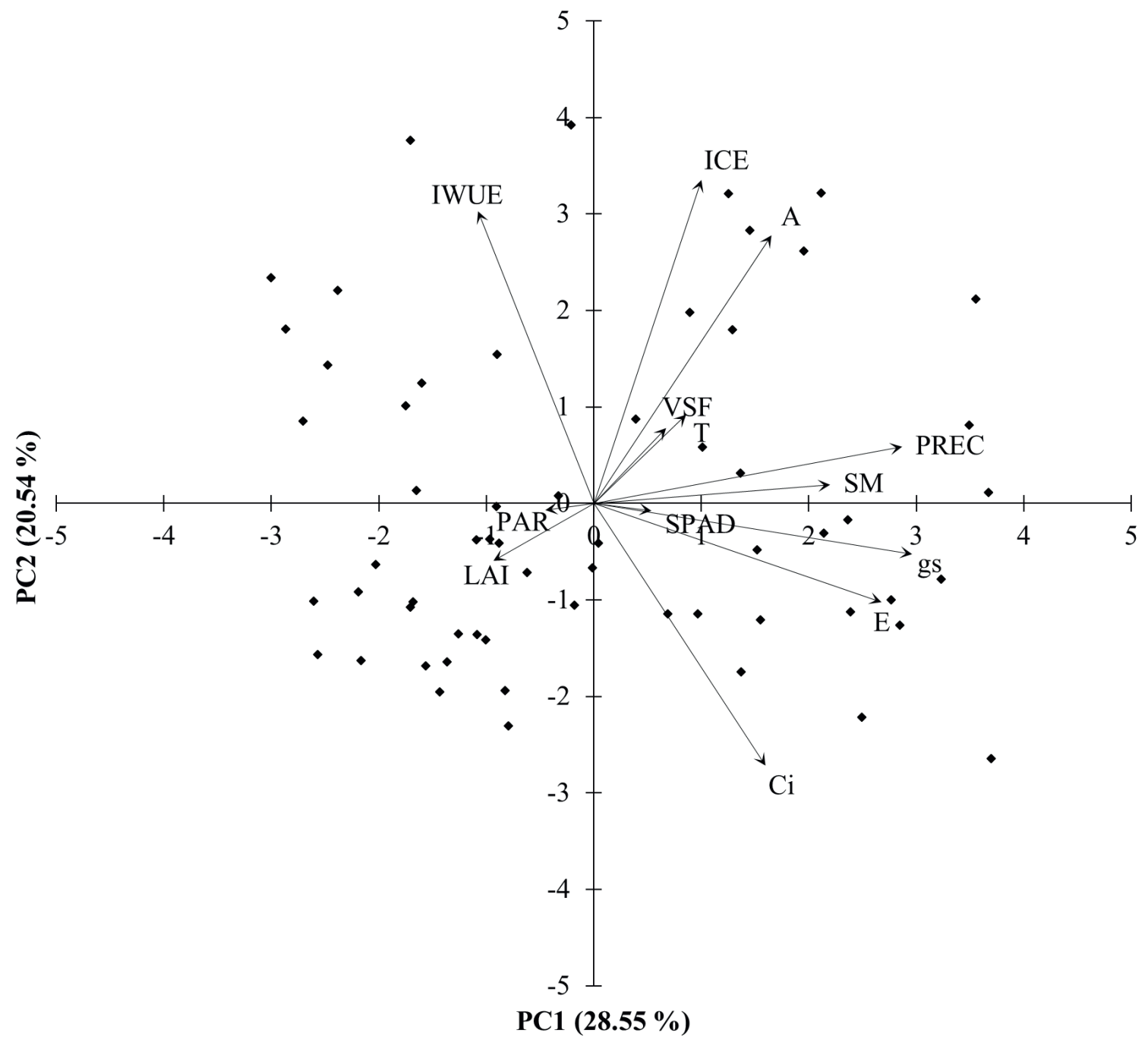

Figure 3. Principal Component Analysis (PCA; PCA1 and PCA2) among the variables of Group I and Group II. The abbreviations are provided in Table 3. 

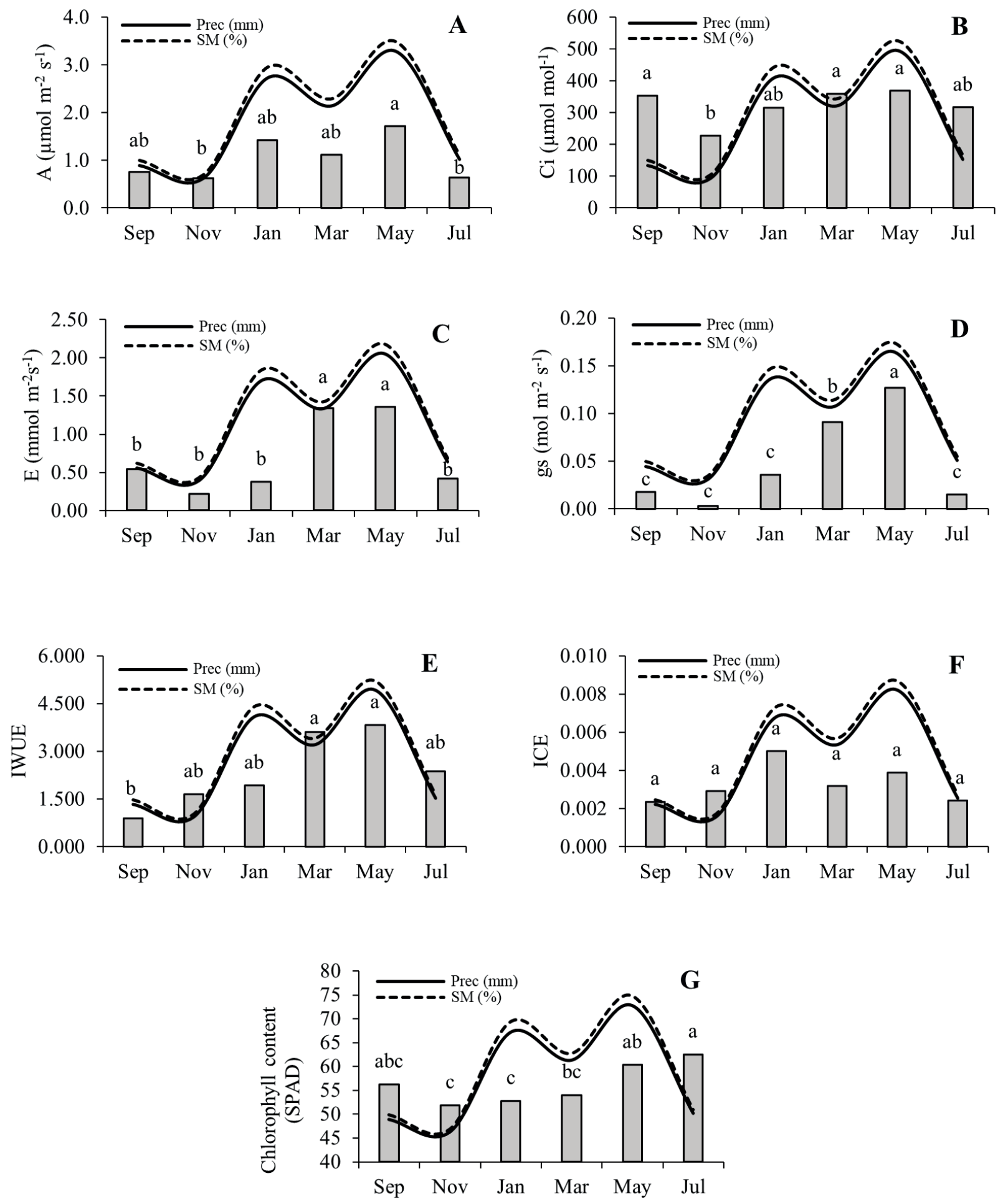

Figure 4. Means of physiological variables, together with rainfall ( $\mathrm{mm}$ ) and soil moisture (\%) for E. simonis, measured at different times of the year (months), in Parque Estadual Mata do Pau-Ferro, municipality of Areia, state of Paraiba, Brazil: A. photosynthetic rate; B. internal $\mathrm{CO}_{2}$ concentration; $\mathbf{C}$. transpiration; D. stomatal conductance; $\mathbf{E}$. instantaneous water use efficiency; F. instantaneous carboxylation efficiency; and G. chlorophyll content (SPAD). * Averages followed by the same letter do not differ among themselves by the Tukey test at $5 \%$ of probability. 
changes to luminosity by the canopy structure indices (LAI and PAR) in the understory because LAI and PAR were constant throughout the study. On the other hand, seasonal variation in gas exchange may be modulated more by edaphic factors, mainly the availability of water in the soil, as observed in other forest species (Campelo et al. 2015), as well as herbaceous species (Holmes \& Klein 1986).

The high water deficit found for the soil during the dry season (Allen \& Pearcy 2000; Sendall et al. 2009; Tonello \& Teixeira Filho 2012; Cunha et al. 2013) may have been responsible for the low photosynthetic rate observed during that period. A reduction in photosynthetic rate is related to a lower internal concentration of $\mathrm{CO}_{2}(\mathrm{Ci})$ and lower stomatal conductance (gs) resulting from the closure of stomata in response to abiotic stresses during the dry season (Sharkey 1990; Pallardy 2008; Dalmagro et al. 2011; Taiz \& Zeiger 2013; Dalastra et al. 2014; Taiz et al. 2017). The lower the water availability the less ATP and NADPH generated and, as a result, less $\mathrm{CO}_{2}$ is fixed. Consequently, photosystem II depends on water to generate chemical energy, which is used to fixate $\mathrm{CO}_{2}$. Therefore, seasonal variation results in lower efficiency of photosystem II, which is why seasonality effects on photosynthetic rate (A) during the dry season are caused by a non-stomatal factor.

The internal $\mathrm{CO}_{2}$ concentration of plants is directly influenced by photosynthesis and is extremely important for the productivity of terrestrial ecosystems (Mello et al. 2015). During the process of $\mathrm{CO}_{2}$ assimilation plants absorb carbon dioxide and transform it into biomass, using water and sunlight, and release $\mathrm{O}_{2}$ into the atmosphere (Taiz et al. 2017). Consequently, photosynthesis has a direct influence on the amount of carbon stocked in vegetal biomass (Ribeiro et al. 2010; Simkin et al. 2015; Lawson et al. 2016).

Stomatal closure reduces the internal concentration of $\mathrm{CO}_{2}(\mathrm{Ci})$ in the leaf mesophyll due to diffusive $\mathrm{CO}_{2}$ resistance in the leaves, with a consequent reduction in the photosynthesis rate (A) (Lawlor 2002; Loreto et al. 2003; Dias \& Marenco 2007; Dalastra et al. 2014). In this sense, water availability and $\mathrm{Ci}$ may represent limiting factors for photosynthesis, especially due to the restriction to gas conduction in the leaf (Kerbauy 2008; Wehr et al. 2016; Aguiar-González et al. 2016).

Variation in chlorophyll level among different seasons may be attributed to the sensibility of this pigment to increased water stress, which may result in the reduction of plant defenses, especially during the dry season, which is in areement with the results found by other researchers (Smirnoff 1995; Larcher 2006; Kiani et al. 2008; Hayatu \& Mukhtar 2010; Moura et al. 2016; Kargar et al. 2017).

In this sense, water deficit reduces the photosynthetic rate by closing stomata, which decreases the efficiency of the carbon fixation process, thereby decreasing the formation and expansion of leaf area and accelerating senescence and leaf abscission (Kozlowski \& Pallardy 1996; Larcher 2006; Dutra et al. 2012; Taiz \& Zeiger 2013; Taiz et al. 2017). In addition, the reduction of transpiration during the dry season represents a mechanism that helps reduce the rapid exhaustion of soil water by plants (Larcher 2006). This physiological strategy to avoid excessive loss of water by transpiration can be considered a mechanism that favors the growth of leaves in drier seasons (Kozlowski \& Pallardy 1996; Silva et al. 2008; Scalon et al. 2011; Campelo et al. 2015).

Inversely, water surplus during the rainy season contributed to higher photosynthetic rates (Larcher 2006; Tatagiba et al. 2008; 2015; Llusia et al. 2016; Zhang et al. 2017), due to greater stomatal opening resulting from the water surplus in the soil, which may have also influenced the higher relative chlorophyll content and higher transpiration values in this season. The high values for photosynthetic rate can be explained by less strict and necessary stomatal control, since the atmosphere and the soil remain with good water availability; that is, the presence of a water surplus (Taiz et al. 2017). Consequently, the availability of an adequate amount of water in the soil during the rainy season (while in the dry season there was not enough water in the soil) allowed individuals of $E$. simonis to exhibit high rates of transpiration.

Instantaneous water use efficiency is determined by the relationship between the rate of photosynthesis and transpiration $(\mathrm{A} / \mathrm{E})$, where the values measured relate the amount of carbon the plant receives per unit of water lost (Jaimez et al. 2005). Based on this principle, the increases observed in IWUE, notably from September to July, are a reflection of increases in photosynthetic rate in individuals of E. simonis. Therefore, Larcher (2006), Melo et al. (2010), Taiz \& Zeiger (2013) and Taiz et al. (2017) stated that gas exchange is influenced by environmental conditions. In this sense, the observed decreases in instantaneous water use efficiency in the driest months may be related to lower water availability.

Instantaneous carboxylation efficiency did not show significant differences among the different months of the year. The high values of internal $\mathrm{CO}_{2}$ concentration associated with increased stomata conductance may indicate an increase in instantaneous carboxylation efficiency (Silva 2012; Silva et al. 2015), however, this was not the case in the present study where ICE values remained constant throughout the months of evaluation. For Machado et al. (2005), ICE bore little resemblance to internal $\mathrm{CO}_{2}$ concentration and the rate of assimilation of carbon dioxide.

\section{Conclusions}

Seasonality was observed to influence the ecophysiology of $E$. simonis, with a greater influence of rainfall and soil moisture on stomatal conductance, transpiration and photosynthetic rate of E. simonies. On the other hand, with water stress during the dry season the species exhibited distinct physiological responses, with lower photosynthetic 


\section{João Everthon da Silva Ribeiro, Ana Jéssica Soares Barbosa, Sérgio de Faria Lopes, Walter Esfrain Pereira and Manoel Bandeira de Albuquerque}

rates due to the closure of stomata as a physiological strategy to avoid excessive water loss.

\section{Acknowledgements}

We thank to the CAPES (Coordenação de Aperfeiçoamento de Pessoal de Nivel Superior) for the scholarship of the first and second author. SFL thanks the CNPq productivity grant awarded.

\section{References}

Aguiar-González B, Ponsoni L, Ridderinkhof H, Aken HMV, Ruijter WPM, Maas LRM. 2016. Seasonal variation of the South Indian tropical gyre. Deep-Sea Research 110: 123-140.

Allen MT, Pearcy RW. 2000. Stomatal behavior and photosynthetic performance under dynamic light regimes in a seasonally dry tropical rain forest. Oecologia 122: 470-478.

Almeida LP, Alvarenga AA, Castro EM, Zanela SM, Vieira CV. 2004. Crescimento inicial de plantas de Cryptocaria aschersoniana Mez. submetidas a níveis de radiação solar. Ciência Rural 34: 83-88.

Balch JK, Massad TJ, Brando PM, Nepstad DC, Curran LM. 2013. Effects of high-frequency understorey fires on woody plant regeneration in southeastern Amazonian forests. Biological Sciences 368: 1-10.

Barbosa MRV, Agra MF, Sampaio EVSB, Cunha JP, Andrade LA. 2004. Diversidade Florística na Mata do Pau-Ferro, Areia, Paraíba. In: Pôrto KC, Cabral JJP, Tabarelli M. (eds.) Brejos de altitude em Pernambuco e Paraíba. Brasília, Ministério do Meio Ambiente. p. 111-121.

Bianchini E, Pimenta JA, Santos FAM. 2001. Spatial and temporal variation in the canopy cover in a tropical semi-deciduous forest. Brazilian Archives of Biology and Technology 44: 269-276.

Braz VS, Kanegae MF, Franco AC. 2000. Estabelecimento e desenvolvimento de Dalbergia miscolobium Benth. em duas fitofisionomias típicas dos cerrados do Brasil central. Acta Botanica Brasilica 14: 27-35.

Brito MEB, Soares LAA, Fernandes PD, Lima GS, Sá FVS, Melo AS. 2012. Comportamento fisiológico de combinações copa/porta-enxerto de citros sob estresse hídrico. Revista Brasileira de Ciências Agrárias 7: 857-865.

Campelo DH, Lacerda CF, Sousa JA, et al. 2015. Trocas gasosas e eficiência do fotossistema II em plantas adultas de seis espécies florestais em função do suprimento de água no solo. Revista Ârvore 39: 973-983.

Cody R. 2015. An introduction to SAS ${ }^{\circledR}$ university edition. Cary, SAS Institute.

Cunha RLM, Filho BGS, Costa RCL, Viégas IJM. 2013. Physiological assessment in young Brazilian and African mahogany plants during the dry and rainy seasons in northeastern Pará state, Brazil. Revista Ciências Agrárias 56: 255-260.

Dalastra GM, Echer MM, Guimaraes VF, Hachmann TL, Inagaki AM. 2014. Trocas gasosas e produtividade de três cultivares de meloeiro conduzidos com um e dois frutos por planta. Bragantia 73: 365-371.

Dalmagro JH, Lobo FA, Ortíz CER, et al. 2011. Trocas gasosas de uma espécie Lenhosa na floresta de transição Amazônia-Cerrado. Ciência e Natura 33: 147-165.

Davis MA, Wrage KJ, Reich PB, Tjoelker MG, Schaeffer T, Muermann C. 1999. Survival, growth and photosynthesis of tree seedlings competing with herbaceous vegetation along a water-light nitrogen gradient. Plant Ecology 145: 341-350.

Dias DP, Marenco RA. 2007. Fotossíntese e fotoinibição em mogno e acariquara em função da luminosidade e temperatura foliar. Pesquisa Agropecuária Brasileira 42: 305-311.

Dutra CC, Prado EAF, Paim LR, Scalon SPQ. 2012. Desenvolvimento de plantas de girassol sob diferentes condições de fornecimento de água. Semina 33: 2657-2668.

Fabricante JR. 2013. Sociabilidade de espécies da mata atlântica com a exótica invasora Artocarpus heterophyllus Lam. Revista de Biologia Neotropical 10: 18-25.
Flexas J, Barbour MM, Brendel O, et al. 2012. Mesophyll diffusion conductance to $\mathrm{CO}_{2}$ : An unappreciated central player in photosynthesis. Plant Science 193: 70-84.

Frazer GW, Canham CD, Lertzman KP. 1999. Gap Light Analyzer (GLA). Version 2.0: Imaging software to extract canopy structure and gap light transmission indices from true-color fisheye photographs, users manual and program documentation. Millbrook/ New York, Simon Fraser University/ Institute of Ecosystem Studies.

Galvani E, Lima NGB. 2014. Fotografias hemisféricas em estudos microclimáticos: Referencial teórico-conceitual e aplicações. Ciência e Natura 36: 215-221.

Gardner TA, Barlow J, Sodhi NS, Peres CA. 2010. A multiregion assessment of tropical forest biodiversity in a human-modified world. Biological Conservation 143: 2293-2300.

Guariguata MR, Kattan GH. 2002. Ecología y conservación de bosques neotropicales. Cartago, Ediciones LUR.

Hair JF, Anderson RE, Tatham RL, Black WC. 2005. Análise multivariada de dados. 5th. edn. Porto Alegre, Bookman.

Hair JF, Black W, Babin B, Anderson RE, Tatham RL. 2009. Análise multivariada de dados. 6th. edn. Porto Alegre, Bookman.

Hayatu M, Mukhtar FB. 2010. Physiological responses of some drought resistance cowpea genotypes (Vigna unguiculata (L.) Walp) to water stress. Bayero Journal of Pure Applied Sciences 03: 69-75.

Holmes GM, Klein WH. 1986. Photocontrol of dark circadian rhythms in stomata of Phaseolus vulgaris L. Plant Physiology 82: 28-33.

Jaimez RE, Rada F, García-Núñez C, Azócarb A. 2005. Seasonal variations in leaf gas exchange of platain cv. 'Hartón' (Musa AAB) under different soil water conditions in a humid tropical region. Scientia Horticulturae 104: 79-89.

Kargar M, Suresh R, Legrand M, Jutras P, Clark OG, Prasher SO. 2017. Reduction in water stress for tree saplings using hydrogels in soil. Journal of Geoscience and Environment Protection 5: 27-39.

Kerbauy GB. 2008. Fisiologia Vegetal. 2nd edn. Rio de Janeiro, Guanabara Koogan.

Kiani SP, Maury P, Sarrafi A, Grieu P. 2008. QTL analysis of chlorophyll fluorescence parameters in sunflower (Helianthus annuus L.) under wellwatered and water-stressed conditions. Plant Science 175: 565-573.

Klein VA. 2008. Física do solo. Passo Fundo, Universidade de Passo Fundo.

Kozlowski TT, Pallardy SG. 1996. Physiology of woody plants. 2nd. edn. San Diego, Academic Press.

Kunz JH, Bergonci JI, Bergamaschi H, Dalmago GA, Heckler BMM, Comiran F. 2007. Uso da radiação solar pelo milho sob diferentes preparos do solo, espaçamento e disponibilidade hídrica. Pesquisa Agropecuária Brasileira 42: 15111520.

Lage-Pinto F, Bernini E, Oliveira JG, Nascimento MT, Vitória AP. 2015. Ecophysiology of two tropical species in an abandoned eucalyptus plantation: effect of plant litter removal and seasonality. Biotemas 28: 27-37.

Larcher W. 2006. Ecofisiologia vegetal. São Carlos, RIMA.

Lawlor DW. 2002. Limitation to photosynthesis in water-stressed leaves: stomata vs. metabolism and the role of ATP. Annals of Botany 89: 871-885.

Lawson JR, Kirstie A, Fryirs KA, Leishman MR. 2016. Interactive effects of waterlogging and atmospheric $\mathrm{CO}_{2}$ concentration on gas exchange, growth and functional traits of Australian riparian tree seedlings. Ecohydrology 2016: 1-11.

Leal RO. 2016. Aspectos ecofisiológicos de espécies arbustivo-arbóreas em condições contrastantes de luminosidade. Monograph, Universidade Federal do Recôncavo da Bahia, Cruz das Almas.

Lemos-Filho JP. 2000. Photoinhibition in three "cerrado" species (Annona crassifolia, Eugenia dysenterica and Campomanesia adamantium), in the dry and rainy seasons. Revista Brasileira de Botânica 23: 45-50.

Llusia J, Roahtyn S, Yakir D, et al. 2016. Photosynthesis, stomatal conductance and terpene emission response to water availability in dry and mesic Mediterranean forests. Trees 30: 749-759.

Loiola MIB, Agra MF, Baracho GS, Queiroz RT. 2007. Flora da Paraíba, Brasil: Erythroxylaceae Kunth. Acta Botanica Brasilica 21: 473-487.

Loiola MIB, Costa-Lima JL. 2015. Erythroxylaceae. In: Lista de Espécies da Flora do Brasil. Rio de Janeiro, Jardim Botânico do Rio de Janeiro. http://floradobrasil.jbrj.gov.br/jabot/floradobrasil/FB7730 
Loreto F, Centritto M, Chartzoulakis K. 2003. Photosynthetic limitations in olive cultivars with different sensitivity to salt stress. Plant, Cell and Environment 26: 595-601.

Machado EC, Schmidt PT, Medina CL, Ribeiro RV. 2005. Respostas da fotossíntese de três espécies de citros a fatores ambientais. Pesquisa Agropecuária Brasileira 40: 1161-1170.

Marenco RA, Antezana-Vera SA, Gouvêa PRS, Camargo MAB, Oliveira MF, Santos JKS. 2014. Fisiologia de espécies florestais da Amazônia: fotossíntese, respiração e relações hídricas. Revista Ceres 61: 786-799.

Marenco RA, Lopes NF. 2009. Fisiologia vegetal: fotossíntese, respiração, relações hídricas e nutrição mineral. 3rd. edn. Viçosa, Editora UFV.

Mayo SJ, Fevereiro VPB. 1982. Mata do Pau-Ferro: a pilot study of the brejo forest. London, Royal Botanic Gardens.

Mello JM, Couto EG, Amorim RSS, Chig LA, Johnson MS, Lobo FA. 2015. Dinâmica dos atributos físicoquímicos e variação sazonal dos estoques de carbono no solo em diferentes fitofisionomias do Pantanal Norte Mato-Grossense. Revista Árvore 39: 325-336.

Melo AS, Silva Júnior CD, Fernandes PD, Sobral LF, Brito MEB, Dantas JDM. 2009. Alterações das características fisiológicas da bananeira sob condições de fertirrigação. Ciência Rural 39: 733-741.

Melo AS, Suassuna JF, Fernandes PD, Brito MEB, Suassuna AF, Aguiar Netto AO. 2010. Crescimento vegetativo, resistência estomática, eficiência fotossintética e rendimento do fruto da melancieira em diferentes níveis de água. Acta Scientiarum Agronomy 32: 73-79.

Mendes KR. 2009. Efeito da sazonalidade da precipitação no crescimento e trocas gasosas em espécies arbóreas numa floresta de terra-firme da Amazônia Central. MSc Thesis, Instituto Nacional de Pesquisas da Amazônia, Manaus.

Mendes KR, Marenco RA, Magalhães NS. 2013b. Crescimento e eficiência fotossintética de uso do nitrogênio e fósforo em espécies florestais da Amazônia na fase juvenil. Revista Árvore 37: 707-716.

Mendes MMS, Lacerda CF, Cavalcante ACR, Fernandes FÉP, Oliveira TS. 2013a. Desenvolvimento do milho sob influência de árvores de pau branco em sistema agrossilvipastoril. Pesquisa Agropecuária Brasileira 48: 1342-1350.

Monte MA, Reis MGF, Reis GG, Leite HG, Stocks JJ. 2007. Métodos indiretos de estimação da cobertura de dossel em povoamentos de clone de eucalipto. Pesquisa Agropecuária Brasileira 42: 769-775.

Moraes IS, Lima AMM, Adami M, Andrade MTVS. 2016. Monitoramento da abertura no dossel a partir de fotografias hemisféricas com NDVI e MLME em área de concessão florestal: Mamuru-Arapiuns/PA. Revista Brasileira de Cartografia 68: 1303-1315.

Moura AR, Nogueira RJMC, Silva JAAS, Lima TV. 2016. Relações hídricas e solutos orgânicos em plantas jovens de Jatropha curcas L. sob diferentes regimes hídricos. Ciência Florestal 26: 345-354.

Nepstad Dc, Moutinho P, Dias Mb, et al. 2002. The effects of partial throughfall exclusion on canopy processes, aboveground production, and biogeochemistry of an Amazon Forest. Journal of Geophysical Research 107: 1-18.

Oliveira FX, Andrade LA, Félix LP. 2006. Comparações florísticas e estruturais entre comunidades de Floresta Ombrófila Aberta com diferentes idades, no Município de Areia, PB, Brasil. Acta Botanica Brasilica 20: 861-873.

Oliveira RJ, Mantovani W, Melo MMRF. 2001. Estrutura do componente arbustivo-arbóreo da floresta atlântica de encosta, Peruíbe, SP. Acta Botanica Brasilica 15: 391-412.

Palhares D, Franco AC, Zaidan LBP. 2010. Photosynthetic responses of Cerrado plants during the rainy and dry seasons. Brazilian Journal of Biociences 8: 213-220.

Pallardy SG. 2008. Physiology of woody plants. 3rd. edn. San Diego, Academic Press.

Pan Y, Birdsey RA, Fang J, et al. 2011. A large and persistent carbon sink in the world' forests. Science 333: 988-993.

Peel MC, Finlayson BL, McMahon TA. 2007. Updated world map of the Köppen-Geiger climate classification. Hydrology and Earth System Sciences 11: 1633-1644

Pennington RT, Lewis GP, Ratter JA. 2006. Neotropical Savannas and Seasonally Dry Forests: Plant Diversity, Biogeography, and Conservation. Boca Raton, CRC Press.
Pezzopane JEM, Reis GG, Reis MGF, Costa JMN. 2005. Caracterização da radiação solar em fragmento de Mata Atlântica. Revista Brasileira de Agrometeorologia 13: 11-19.

Pezzopane JEM, Reis GG, Reis MGF, Costa JMN, Chaves JH. 2002. Temperatura do solo no interior de um fragmento de floresta secundária semidecidual. Revista Brasileira de Agrometeorologia 10: $1-8$.

Prado Júnior J, Schiavini I, Vale V, Lopes S, Arantes C, Oliveira AP. 2015. Functional leaf traits of understory species: strategies to different disturbance severities. Brazilian Journal of Biology 75: 339-346.

Rebelatto D, Leal TS, Moraes CP. 2013. Fenologia de duas espécies de Ipê em uma área urbana no município de Araras, São Paulo, Brasil. Revista da Sociedade Brasileira de Arborização Urbana 8: 1-16.

Ribeiro SC, Jacovine LAG, Soares CPB, Martins SV, Nardelli AMB, Souza AL. 2010. Quantificação de biomassa e estimativa de estoque de carbono em uma capoeira da zona da mata mineira. Revista Árvore 34: 495-504.

Rody YP, Ribeiro A, Pezzopane JEM, Gleriani JM, Almeida AQ, Leite FP. 2014. Estimativas do índice de área foliar utilizando o LAI-2000 e fotografias hemisféricas em plantios de eucalipto. Ciência Florestal 24: 925-934.

Scalon SPQ, Mussury RM, Euzébio VLM, Kodama FM, Kissmann C. 2011. Estresse hídrico no metabolismo e crescimento inicial de mudas de mutambo (Guazuma ulmifolia Lam.). Ciência Florestal 21: 655-662.

Sendall KM, Vourlitis GL, Lobo FA. 2009. Seasonal variation in the maximum rate of leaf gas exchange of canopy and understory tree species in an Amazonian semi-deciduous forest. Brazilian Journal of Plant Physiology 21: 65-74.

Sharkey TD. 1990. Water stress effects on photosynthesis. Photosynthetica 24: 651- 656.

Silva AS, Oliveira JG, Cunha M, Vitória AP. 2010. Photosynthetic performance and anatomical adaptations in Byrsonima sericea DC. under contrasting light conditions in a remnant of the Atlantic forest. Brazilian Journal of Plant Physiology 22: 245-254.

Silva FG. 2012. Comportamento fisiológico da berinjela cultivada em ambiente protegido sob taxas de reposição hídrica. Monograph, Universidade Estadual da Paraíba, Catolé do Rocha.

Silva FG, Dutra WF, Dutra AF, Oliveira IM, Filgueiras LMB, Melo AS. 2015. Trocas gasosas e fluorescência da clorofila em plantas de berinjela sob lâminas de irrigação. Revista Brasileira de Engenharia Agrícola e Ambiental 19: 946-952.

Silva JR, Mailard F, Costa-Pereira PS, Andrade CF. 2009. Comparação de métodos indiretos para medição de abertura do dossel no cerrado, utilizando observações obtidas nos trabalhos de campo e fotos hemisféricas digitais. In: Anais do XIV Simpósio Brasileiro de Sensoriamento Remoto. Natal, INPE. p. 3059-3064.

Silva MAV, Nogueira RJMC, Oliveira AFM, Santos VF. 2008. Resposta estomática e produção de matéria seca em plantas jovens de aroeira submetidas a diferentes regimes hídricos. Revista Árvore 32: 335-344.

Silva MC, Queiroz JER, Araujo KD, Pazera-Jr E. 2006. Condições ambientais da Reserva Ecológica Estadual da Mata do Pau-Ferro, Areia - PB. Geografia 15: 51-63.

Silvério DV, Lenza E. 2010. Fenologia de espécies lenhosas em um cerrado típico no Parque Municipal do Bacaba, Nova Xavantina, Mato Grosso, Brasil. Biota Neotrópica 10: 205-216.

Simkin AJ, McAusland L, Headland LR, Lawson T, Raines CA. 2015. Multigene manipulation of photosynthetic carbon assimilation increases $\mathrm{CO}_{2}$ fixation and biomass yield in tobacco. Journal of Experimental Botany 66: 4075-4090.

Smirnoff N. 1995. Metabolic flexibility in relation to the environment. Environment and plant metabolism: flexibility and acclimation. Oxford, Bios Scientific Publishers.

Taiz L, Zeiger E. 2013. Fisiologia Vegetal. 5th. edn. Porto Alegre, Artmed.

Taiz L, Zeiger E, Møller IM, Murphy A. 2017. Fisiologia e desenvolvimento vegetal. 6 th. edn. Porto Alegre, Artmed.

Tatagiba SD, Pezzopane JEM, Reis EF. 2008. Relações hídricas e trocas gasosas na seleção precoce de clones de eucalipto para ambientes com diferenciada disponibilidade de água no solo. Floresta 38: 387-400.

Tatagiba SD, Pezzopane JEM, Reis EF. 2015. Fotossíntese em Eucalyptus sob diferentes condições edafoclimáticas. Engenharia na Agricultura 23: $336-345$ 


\section{João Everthon da Silva Ribeiro, Ana Jéssica Soares Barbosa, Sérgio de Faria Lopes, Walter Esfrain Pereira and Manoel Bandeira de Albuquerque}

Tonello KC, Teixeira Filho J. 2012. Ecofisiologia de três espécies arbóreas nativas da mata atlântica do Brasil em diferentes regimes de água. Irriga 17: 85-101.

Vessoni F. 1998. Correlação Canônica. http://blue.mv2.com.br/wp-content/ uploads/2015/06/Correlacao_Canonica.pdf

Vieira TO. 2013. Plasticidade fenotípica e aclimatação de Siparuna guianensis em resposta a gradiente de luz. MSc Thesis, Universidade Estadual do Norte Fluminense, Campos dos Goytacazes.

Wehr R, Munger JW, McManus JB, et al. 2016. Seasonality of temperate forest photosynthesis and daytime respiration. Nature 534: 680-683.

Welles JM, Norman JM. 1991. Instrument for indirect measurement of canopy architecture. Agronomy Journal 83: 818-825.

Whitford KR, Colquhoun IJ, Lang ARG, Harper BM. 1995. Measuring leaf area index in a sparse eucalypt forest: a comparison of estimates from direct measurement, hemispherical photography, sunlight transmittance and allometric regression. Agricultural and Forest Meteorology 74: 237-249.

Zhang S, Li Q, Ma K, Chen L. 2001. Temperature-dependent gas exchange and stomatal/non-stomatal limitation to $\mathrm{CO}_{2}$ assimilation of Quercus liaotungensis under midday high irradiance. Photosynthetica 39: 383-388.

Zhang Y, Chen JM, Miller JR. 2005. Determining digital hemispherical photograph exposure for leaf area index estimation. Agricultural and Forest Meteorology 133: 166-181.

Zhang YJ, Sack L, Cao KF, Wei XM, Li N. 2017. Speed versus endurance tradeoff in plants: Leaves with higher photosynthetic rates show stronger seasonal declines. Scientific Reports 7: 1-8. 